\title{
Functional characterization of p53 in nasopharyngeal carcinoma by stable shRNA expression
}

\author{
YI SUN ${ }^{1-3}$, HONG YI $^{1}$, YIXUAN YANG ${ }^{1}$, YANHUI YU ${ }^{1}$, YONGMEI OUYANG ${ }^{1}$, \\ FANG YANG $^{1,2}$, ZHIQIANG XIAO ${ }^{1}$ and ZHUCHU CHEN ${ }^{1,2}$ \\ ${ }^{1}$ Key Laboratory of Cancer Proteomics of Chinese Ministry of Health, Xiangya Hospital, ${ }^{2}$ Cancer Research Institute, \\ and ${ }^{3}$ Human Reproductive and Stem Cell Engineering Institute, Central South University, Changsha, P.R. China
}

Received November 6, 2008; Accepted December 30, 2008

DOI: 10.3892/ijo_00000227

\begin{abstract}
Nasopharyngeal carcinoma (NPC) is a highincidence malignancy in Southern China and Southeast Asia. Although mutation of p53 tumor-suppressor gene is a rare event in NPC, NPC has a high frequency of over-expressed/ accumulated $\mathrm{p} 53$ protein, which was reported to be dysfunction or inactivation in most of NPC. We report here a functional characterization of p53 in an undifferentiated NPC cell line CNE2. To elucidate the biological function of p53, we employed the RNA interference (RNAi) approach to knockdown the endogenously expressed p53 in CNE2 cells. Interestingly, suppression of p53 expression in CNE2 cells was associated with significant down-regulation of $\mathrm{p} 21^{\mathrm{WAF} 1 / \mathrm{CIP} 1}$ expression and decreased HDM2 protein level in both steady state and genotoxic stress induced by ionizing radiation (IR). Consistent with these biochemical data were the accelerated cell cycle progression and the increased proliferation rate, suggesting that p53 retained growth inhibitory activity in CNE2 cells. Indeed, down-regulation of p53 in CNE2 enhanced the ability of CNE2 cells to grow anchorage-independently in vitro and to develop tumors in vivo. Together with the radioresistance acquired by CNE2sip53 cells, our data indicate that in contrast to a previous study, p53 in this NPC cell line remains functional, which may have an important therapeutical implication.
\end{abstract}

\section{Introduction}

Nasopharyngeal carcinoma (NPC) is featured by a remarkable racial and geographic distribution, and is a high-incidence

Correspondence to: Dr Zhiqiang Xiao, Key Laboratory of Cancer Proteomics of Chinese Ministry of Health, Xiangya Hospital, Central South University, Changsha 410008, P.R. China

E-mail: zqxiao2001@yahoo.com.cn

Dr Zhuchu Chen, Cancer Research Institute, Xiangya School of Medicine, Central South University, Changsha 410078, P.R. China E-mail: tcbl@xysm.net

Key words: nasopharyngeal carcinoma, p53, RNAi, shRNA malignancy in Southern China, Southeast Asia, Northern Africa, and Alaska, where the observed incidence rates range from 15 to 50 per 100,000 persons (1-3). NPC can occur in all age groups, but has a bimodal age distribution. The incidence peaks at 50 to 60 years of age; and a small peak is observed during late childhood (3). As an etiologically multi-factorial disease, carcinogenesis of the nasopharynx may result from combined effects of Epstein-Barr viral (EBV), genetic and environmental factors (4-7). Available information on the origin of NPC suggests that genetic alterations of tumor suppressor genes and proto-oncogenes in multiple cellular pathways may be important in multistage NPC carcinogenesis.

p53 tumor-suppressor protein plays a pivotal role in regulating cell cycle, differentiation and apoptosis (8). As a transcription factor, p53 can induce the expression of p21 $1^{\mathrm{WAF} 1 / \mathrm{CIP} 1}$, which inhibits cyclin-dependent kinases, thereby preventing the phosphorylation of $\mathrm{Rb}$ and subsequent cell cycle arrest (9). Mutation of p53 tumor-suppressor gene has been found to be the most frequent genetic alteration in human malignancy. p53 mutations often result in accumulation of the mutant p53 protein, which either loses tumor suppressor function or gains oncogenic activity (10). p53 can also be functionally inactivated by mechanisms other than gene mutation (10). Screen for p53 mutations in the hot-spots for mutation revealed only a low frequency of p53 mutations ranging from 0 to $10 \%$, which might explain the initial high sensitivity observed with cisplatin-based induction chemotherapy that achieves a 75-100\% objective response rate even in locally advanced disease (11-14). As compared to other types of cancer, numerous studies showed an overexpression or accumulation of $\mathrm{p} 53$ protein in $>95 \%$ NPC $(15,16)$. From the clinical viewpoint, some reports have shown that $\mathrm{p} 53$ expression has no prognostic significance for NPC patients $(17,18)$. Moreover, there is no correlation of p53 expression with recurrent nodal metastatic NPC (17). However, experimental evidence has confirmed that the overexpression of p53 seems to occur at an early stage in the development of NPC and associated with advanced disease stage, poor response to therapy. Overexpressed p53 protein is believed to have impaired tumor suppressor activity and to contribute to immortalization and cellular transformation $(17,19,20)$. Until now, the activity of overexpressed p53 in the NPC remains unclear and the role of the p53 in NPC is 
still not confirmed. If the overexpressed p53 protein plays a role in carcinogenesis or has tumor-promoting functions, such as the transcriptional activation of genes involved in cell proliferation, cell survival and angiogenesis, it is a potential molecular target for gene therapy. Hence, it is important to verify the function of p53 in NPC.

RNA interference (RNAi) which is a sequence-specific and post-transcriptional gene silencing method initiated by doublestranded RNAs is increasingly being used to specifically inhibit gene expression in mammalian cells (21). Since RNAi represents a powerful tool for determining the functions of specific genes via analysis of loss-of-function phenotype, we used pSUPER vector to express short hairpin RNA ( hRNA) of p53 knocking down overexpressed p53 in human undifferentiated NPC cell line CNE2 to examine the function of p53 in NPC. Interestingly, our data indicate that the overexpressed p53 protein in NPC retains the tumor suppressor activity as knockdown of the expression of p53 in a NPC cell line was associated with enhanced cell proliferation and tumor progression.

\section{Materials and methods}

Construction of recombinant pSUPER plasmid expressing p53-shRNA and eGFP-shRNA. shRNA expression vector pSUPER.retro was a gift from Dr Li Yan (University of Texas M.D. Anderson Cancer Center, TX, USA). shRNAexpressing plasmids targeting human p53 (pSUPER/sip53) and eGFP (pSUPER/sieGFP) were constructed as previously described (22). The target sequences for eGFP (GenBank accession no. U55763) were chemically synthesized (Takara, Japan) as following complementary oligonucleotides: sieGFPa: 5'-gatccccGCTGACCCTGAAGTTCATCttcaagagaGATGA ACTTCAGGGTCAGCtttttggaaa-3'; sieGFPs: 5'-agcttttccaaaa aGCTGACCCTGAAGTTCATCtctcttgaaGATGAACT TCAGGGTCAGCggg-3'.

Cell culture, transient or stable transfection. NPC cell line CNE2 was cultured and the stable transfection cell lines expressing p53 or eGFP shRNA were established as described previously (22). The stable transfection cell line expressing p53 shRNA were determined by reverse-transcription PCR (RT-PCR) assay. In the transient transfection experiments, CNE2 cells were seeded at $5 \times 10^{5}$ cells per well in 6-well tissue culture plates. The following day, cells were cotransfected with peGFP and pSUPER/sieGFP plasmid, and with peGFP and pSUPER/sip53 as a control to confirm the specificity of RNA interference in CNE2 cell line and to evaluate the efficiency of transfection.

Preparation of total RNA and RT-PCR. Total RNA was extracted from the cells using TRIzol reagent (Gibco BRL, Grand Island, NY, USA) according to the manufacturer's instructions. Two microgram RNA per sample was reversetranscribed into first-strand cDNA using A3500 reverse transcription system (Promega, USA) in a standard protocol with random oligo(dT) primers. RT-PCR exponential phase was determined on 25-32 cycles to allow semiquantitative comparisons among cDNAs developed from identical reactions. The glyceraldehydes-3-phosphate dehydrogenase
(GAPDH) gene was selected as the internal standard gene. Each PCR regime involved a 5-min initial denaturation step at $94^{\circ} \mathrm{C}$, followed by 29 cycles at $94^{\circ} \mathrm{C}$ for $30 \mathrm{sec}, 55^{\circ} \mathrm{C}$ for $30 \mathrm{sec}$, and $72^{\circ} \mathrm{C}$ for $30 \mathrm{sec}$, and by $72^{\circ} \mathrm{C}$ for $10 \mathrm{~min}$. The expression level of p53 of all puromycin-resistant cell lines were determined by RT-PCR analysis using the following PCR primers: p53s, 5'-CTGGAGTCTTCCAGTGTGAT-3'; p53a, 5'-AGTCACAGCACATGACGGAG-3'; GAPDHs, 5'-GTCAGTGGTGGACCTGACCT-3'; GAPDHa, 5'-TGAG GAGGGGAGATTCAGTG-3'. RT-PCR products were detected by electrophoresis on $1.5 \%$ agarose gel containing ethidium bromide.

Observation of p53 expression by immunofluorescent staining. The cells were plated in chamber slides coated with polyD-lysine (Sigma-Aldrich Co., St. Louis, MO, USA), fixed in ice-cold 4\% paraformaldehyde (Sigma-Aldrich) in phosphatebuffered saline (PBS) for $15 \mathrm{~min}$, washed three times with PBS, and then permeabilized for 5 min with $0.5 \%$ NP40 at room temperature. After washed three times in PBS, the slides were treated for $1 \mathrm{~h}$ with a blocking buffer consisting of $1 \% \mathrm{BSA}$ in $\mathrm{PBS}$ and incubated overnight at $4^{\circ} \mathrm{C}$ with anti-human p53 monoclonal antibody (DO-1, Santa Cruz Biotechnology, Santa Cruz, CA, USA) diluted 1:250 in PBS. After washing three times in PBS containing 1\% BSA, indirect immunofluorescence was obtained by incubation with FITC-conjugated rabbit anti-mouse IgG antibodies (Amersham Biosciences, Stockholm, Sweden) diluted 1:200 in PBS for $1 \mathrm{~h}$ at $37^{\circ} \mathrm{C}$. Nuclei were stained with DAPI. The cells were mounted with $10 \mathrm{mg} / \mathrm{ml}$ of Dabco (Sigma-Aldrich) diluted in $80 \%$ glycerol, and were observed using Olympus $\mathrm{BH}-2$ fluorescence microscope (Japan).

Analysis of $p 21$ and HDM2 expressions by real-time quantitative RT-PCR. Total RNA was extracted using TRIzol reagents (Gibco) according to the manufacturer's instructions. Two microgram RNA per sample was reverse-transcribed into first-strand cDNA by using A3500 reverse transcription system (Promega) in a standard protocol with random oligo(dT) primers. According to the manufacturer's instructions, real-time PCR amplifications were performed on the Roche LightCycler system (Roche Diagnostics, Mannheim, Germany) with SYBR Green I dye, which binds preferentially to doublestrand DNA and enables real-time detection of PCR products. The cDNA was submitted to real-time PCR using the following primer pairs which were derived from the GenBank sequences, and were designed by premier 5.0: p53s, 5'-CCTCCTCAGC ATCTTATCCG-3'; p53a, 5'-CAGCCTGGGCATCCTTG-3'; p21s, 5'-GCAGCGGAACAAGGAGT-3'; p21a, 5'-GGAGA AACGGGAACCAG-3'; HDM2s, 5'-CTGTGTTCAGTGGC GATTGG-3'; HDM2a, 5'-TGGAATCTGTGGGGTGGT-3'; GAPDHs, 5'-GTCAGTGGTGGACCTGACCT-3'; GAPDHa, 5'-TGAGGAGGGGAGATTCAGTG-3'. Briefly, a 20- $\mu$ 1 reaction mixture containing $2 \mu \mathrm{l}$ of cDNA, $2 \mu \mathrm{l}$ of Faststart DNA Master SYBR Green 1 mix (Roche Diagnostics), $0.5 \mu 1$ of $10 \mu \mathrm{mol} / 1$ PCR forward primers, $0.5 \mu 1$ of $10 \mu \mathrm{mol} / 1 \mathrm{PCR}$ reverse primers, $1 \mu \mathrm{l}$ of $25 \mathrm{mmol} / 1 \mathrm{MgCl}_{2}$ and $14 \mu 1 \mathrm{H}_{2} \mathrm{O}$ was loaded into glass capillary tubes, and cycling was carried out as shown in Table I. After each run, the cycle threshold (CT) values were provided from real-time PCR instrumentation 
Table I. Experimental protocol used for quantitative PCR amplification.

\begin{tabular}{|c|c|c|c|c|}
\hline Segment number & Temperature target $\left({ }^{\circ} \mathrm{C}\right)$ & Hold time (sec) & Slope $\left({ }^{\circ} \mathrm{C} / \mathrm{sec}\right)$ & Application mode \\
\hline Program: denaturation & & & Cycles: 1 & \\
\hline 1 & 95 & 10 & 20 & None \\
\hline Program: PCR & & & Cycles: $40-50$ & \\
\hline 1 & 95 & 4 & 20 & None \\
\hline 2 & $\mathrm{x}^{\mathrm{a}}$ & 20 & 20 & None \\
\hline 3 & 72 & 15 & 20 & Single \\
\hline Program: melting & & & Cycles: 1 & \\
\hline 1 & 95 & 0 & 20 & None \\
\hline 2 & 60 & 10 & 20 & None \\
\hline 3 & 95 & 0 & 0.2 & Constant \\
\hline Program: cooling & & & Cycles: 1 & \\
\hline 1 & 40 & 10 & 20 & None \\
\hline
\end{tabular}

${ }^{\mathrm{a}} \mathrm{p} 5352^{\circ} \mathrm{C}, \mathrm{p} 2150^{\circ} \mathrm{C}, \mathrm{HDM} 255^{\circ} \mathrm{C}, \mathrm{GAPDH} 55^{\circ} \mathrm{C}$.

by the LightCycler software. Analysis of the relative gene expression was performed by using the $2^{-\Delta \Lambda C T}$ method described by Livak and Schmittgen (23). Evaluation of $2^{-\triangle \triangle C T}$ indicates the fold change in gene expression relative to the internal standard gene GAPDH and takes into account the standard deviation. Individual CT values were based on three separate measurements. The specificity of the PCR amplification was directly verified by melt-curve analysis of the final products in the iCycler. To verify the melting curve results, all the PCR products were verified by DNA sequencing.

Western blot analyses. Western blot analyses were performed as described previously (22). An anti- $\beta$-actin monoclonal antibody (AC-15) was purchased from Sigma-Aldrich). Antip21 $1^{\text {CIP1/WAF1 }}$ (F5), anti-p53 (DO-1) and anti- HDM2 (D-12) were obtained from Santa Cruz Biotechnology.

Cell cycle analysis by flow cytometry. For cell cycle analysis, two stable expression p53 shRNA cell lines and control cell lines $\left(1 \times 10^{6}\right.$ cells $)$ were harvested, washed twice with cold PBS buffer and fixed with $70 \%$ cold ethanol. After incubation at $4^{\circ} \mathrm{C}$ overnight, cells were washed with PBS, resuspended in FACS buffer containing RNAase A $(0.2 \mu \mathrm{g} / \mathrm{ml})$ and propidium iodide $(20 \mu \mathrm{g} / \mathrm{ml}$, Sigma-Aldrich) and incubated at $37^{\circ} \mathrm{C}$ for $30 \mathrm{~min}$. The stained cells were analyzed on a FACScan flow cytometer (Becton-Dickinson) with excitation at $488 \mathrm{~nm}$ and the emission recorded $675 \mathrm{~nm}$ long pass (FL4, mitoxantrone) filters, and the data were analyzed by the ModFIT/LT software (24).

Analysis of cell growth in vitro. For MTT assay (25), aliquots of cell suspension containing 500 cells in $150 \mu 1$ of medium were transferred into individual well of 96-well tissue culture plates, and were grown for 7 days. Every 24 h, $20 \mu 1$ of MTT ( $5 \mathrm{mg} / \mathrm{ml}$, Sigma-Aldrich) was added to wells, and the medium was removed after $4 \mathrm{~h}$ of incubation. DMSO [150 $\mu \mathrm{l}$ (dimethylsulphoxide, Merck)] was added to each well for $10 \mathrm{~min}$ at room temperature. The absorbance of each well was read with a Bio-Tek Instruments EL310 Microplate Autoreader at $490 \mathrm{~nm}$. The percentage of cell growth was calculated by comparison of the A490 readings versus the first day of absorbance. Each experiment was performed at least three times in triplicate. For the monolayer growth experiment, the cells were seeded at 500 cells per well in 6-well tissue culture plates. After growth for 7 days at $37^{\circ} \mathrm{C}$, the dishes were stained with crystal violet (Sigma-Aldrich) and colonies of $>50$ cells were counted. For the soft agar growth experiment, cells were trypsinized and suspended in $0.3 \%$ agar noble (Difco) containing RPMI-1640 and $10 \%$ FCS at a density of $10^{4}$ cells $/ \mathrm{ml}$. Next, $1 \mathrm{ml}$ of the cell suspension was placed over $1 \mathrm{ml}$ of $0.5 \%$ noble agar containing RPMI-1640 and 10\% FCS in 6-well plates. After plating, $1 \mathrm{ml}$ of RPMI-1640 containing 10\% FCS was added to the soft agar cultures and replenished every 3 days. Cells were allowed to grow for 10 days and colonies consisting of $>50$ cells were counted under an inverted microscope (Olympus, Japan). All assays were performed in triplicate and repeated three times.

In vivo tumorigenicity assay. Animal work was carried out in the animal facility of Xiangya School of Medicine, Central South University in accordance with institutional guidelines. Mice were acclimatized and caged in groups of six or fewer. All mice were fed a diet of animal chow and water ad libitum. Animals were anesthetized with methoxyflurane prior to all procedures and were observed until fully recovered. Cells 
$\left(1 \times 10^{7}\right)$ were subcutaneously inoculated into the right anterior flanks of 4- to 6-week-old athymic BALB/c-nu/nu (nude) mice purchased from the Experimental Centre of Shanghai Drug Institute of Academy of China. After the injection, the animals were examined for tumor formation every 3 days, and the percentages of tumor-bearing animals and the tumor volume were determined. The sizes of the tumors were determined by external measurements of the tumors in two dimensions with a caliper. The tumor volume (V) was calculated according to the formula $\mathrm{V}=L \times l^{2} \times 0.52$ ( $L$ and $l$ represent the widest and the smallest tumor diameter measurements) (26). At the end of the experiment, the mice were sacrificed with a lethal dose of $\mathrm{CO}_{2}$, and each tumor was then excised, measured and fixed in neutralbuffered formalin for routine histologic examination and hematoxylin and eosin staining. The experiment was performed separately with six different animals from each group to confirm reproducibility.

Cell survival determination and Hoechst 33258 staining of apoptotic cells after IR. Dose-effect curves for the loss of colony-forming ability were established. The cells were trypsinized and plated in appropriate densities on 6-well tissue culture plates for the clonogenic survival assay. Cells were irradiated at room temperature, using a Varian CLINAC2100C/D radiotherapy accelerator ( $\gamma$ irradiation; Varian, USA; $6 \mathrm{MV}$, at the dose rate of $300 \mathrm{c} \mathrm{Gy} / \mathrm{min}$ ) in the Department of Radiology, Xiangya Hospital of Central South University. The radiation was delivered as a single dose ranging from 0 to $8 \mathrm{~Gy}$ in an $11 \times 11 \mathrm{~cm}$ field size at a dose rate of $0.5 \mathrm{~Gy} / \mathrm{min}$. Fixation and staining of colonies were carried out 10 days later. Colonies of $>50$ cells were counted. Cell survival was calculated by: (colony numbers of irradiated cells/plating cell numbers)/(colony numbers of sham non-irradiated cells/plating cell numbers) $\times 100 \%$. The survival curves fit to a single-hit multitarget model: $\mathrm{S}$ $(D)=1-\left[1-\exp (-\mathrm{D} / \mathrm{Do})^{\mathrm{N}}\right]$, where Do (dose of radiation producing a $37 \%$ survival rate), is the reciprocal of the slope of the exponential part of the survival curve and $\mathrm{N}$ is the so-called extrapolation number (27). All data presented are mean of at least two independent experiments. The nuclear morphology of cells was examined by staining with the cellpermeable DNA fluorescent dye Hoechst $33258(25 \mu \mathrm{g} / \mathrm{ml}$, Sigma). Cells with homogeneously stained nuclei were considered to be viable, whereas the presence of chromatin condensation and/or fragmentation was indicative of apoptosis. Hoechst staining was performed as described by Perez-Ortiz et al (28). Briefly, cells were grown on chamber slides. After irradiation (+IR, $6 \mathrm{~Gy}$ ), cells were washed with PBS, fixed with $4 \%$ paraformaldehyde for $30 \mathrm{~min}$ at $4{ }^{\circ} \mathrm{C}$, and stained with $25 \mu \mathrm{g} / \mathrm{ml}$ Hoechst 33258 dissolved in Hanks' buffer in the dark for $10 \mathrm{~min}$. Cells were observed using Olympus BH-2 fluorescence microscope (Japan). Apoptotic cells were identified on the basis of the presence of highly condensed or fragmented nuclei. To calculate the percentage of apoptotic cells, at least 200 cells from three different microscopic fields were counted.

Statistical analysis. All observations were confirmed by at least three independent experiments. Analysis of variance
(ANOVA) followed by a Fisher's protected least significant difference (LSD) test was used to analyze all the experiments, and results were expressed as the mean \pm standard deviation (SD). These analyses were done using the Statistical Package for Social Science software (SPSS for windows, version 10.0). A value $(\mathrm{p}<0.05)$ was considered statistically significant.

\section{Results}

Specific gene inhibition by the retroviral vector-mediated shRNA expression in CNE2 cell line. We used the $\mathrm{H} 1$ promoter to drive expression of shRNA targeting human $\mathrm{p} 53$, and eGFP was included as a control. The target sequences were cloned into the BglII/HindIII sites of pSUPER vector (Fig. 1A). In order to verify that silencing was induced by the H1-shRNA constructs with high target specificity, we transiently cotransfected shRNA-expressing plasmids with an eGFP-expressing plasmid into CNE2 cells. The result showed that eGFP fluorescence was effectively reduced after cotransfected with the pSUPER/sieGFP plasmid but not with the pSUPER/sip53 plasmid or pSUPER vector (Fig. 1B). Having verified the plasmids, we generated stable CNE2 cell clones expressing pSUPER/sip53, pSUPER vector or pSUPER/sieGFP. As shown in Fig. 1C, introduction of pSUPER/sip53 into CNE2 cells eliminated p53 mRNA expression levels, while the expression levels of p53 in mock group (Fig. 1C, lane 2) and pSUPER/sieGFP (Fig. 1C, lane 3) were not significantly affected. The p53 protein levels in CNE2sip53-1 and CNE2sip53-2 cells (p1 and p2 cell lines) were also examined by immunofluorescent staining, which showed a decrease over that in control cell lines (Fig. 1D). These results indicated that the vector-delivered RNAi resulted in effective and stable down-regulation of p53 expression in CNE2 cells.

Effects of p53 knockdown on cell cycle progression and the expression of target genes. Having established these stable CNE2 lines, we examined the functional consequence of p53 knockdown. In view of p53 being a transcriptional activator of the p $21^{\mathrm{CIP} 1 / \mathrm{WAF} 1}$ and HDM 2 genes, we determined $\mathrm{p} 21^{\mathrm{CIP} 1 / \mathrm{WAF} 1}$ and HDM2 expression levels in relation to the $\mathrm{p} 53$ down-regulation. The p21 and HDM2 mRNA expression levels of CNE2sip53-1 and CNE2sip53-2 cells were determined by real-time quantitative RT-PCR. As shown in Fig. 2A, in CNE2sip53 cell lines, the p21 mRNA levels were decreased up to $74 \%$ of that in control cells $(\mathrm{p}<0.05)$ and the HDM2 mRNA levels were decreased up to $85 \%$ of that in control cells $(\mathrm{p}<0.05)$, whereas no such decrease was seen in CNE2/pSUPER cells. Consistent with the down-regulation of mRNA, Western blot analysis showed that the p53 protein steady state level in CNE2sip53 cell lines was significantly diminished when compared with the control cell lines including CNE2 and CNE2/pSUPER cell lines (Fig. 2B, first panel, lanes 1-4). Furthermore, Western blot analysis showed a decrease of the level of $\mathrm{p} 21$ protein and a decreased expression of p53 target gene HDM2 in CNE2sip53 cells (Fig. 2B, first panel, lanes 1-4). At the same time, response of CNE2sip53 cell lines, CNE2/pSUPER and CNE2 cells to ionizing radiation (IR) was analyzed by Western blot analysis using the indicated 
A

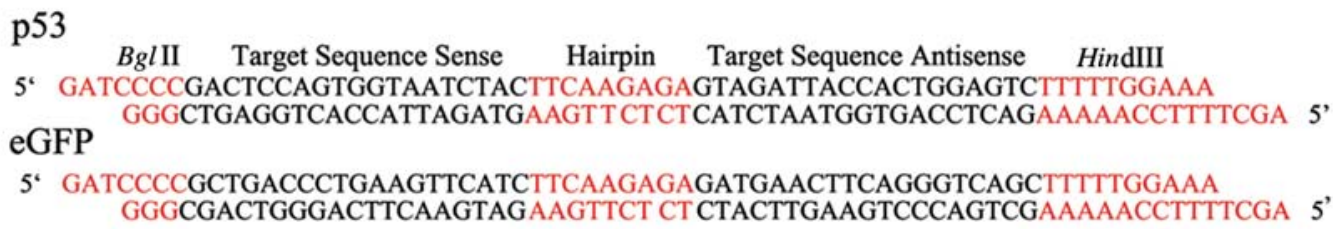

B

peGFP
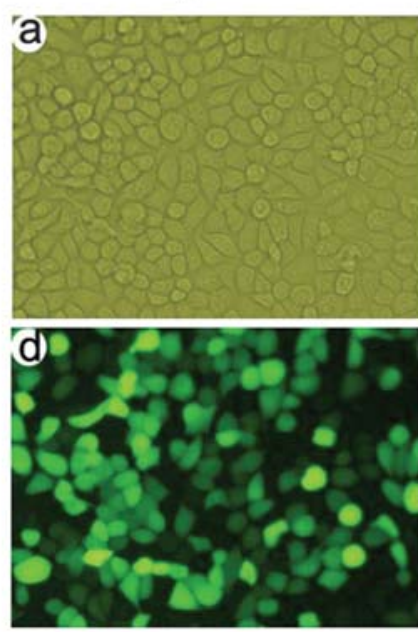

$\mathrm{peGFP}+\mathrm{pSUPER} / \operatorname{sip} 53$
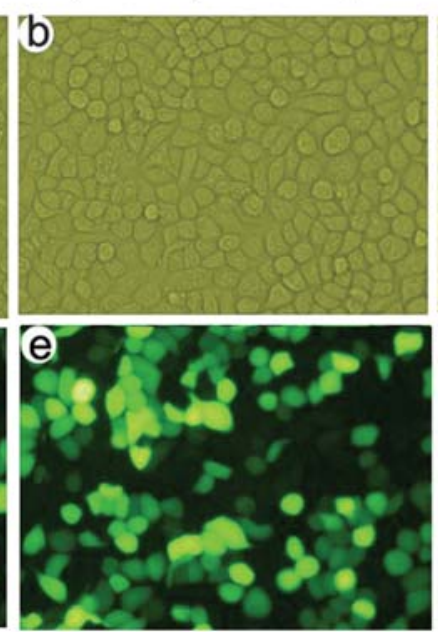

peGFP+pSUPER/sieGFP
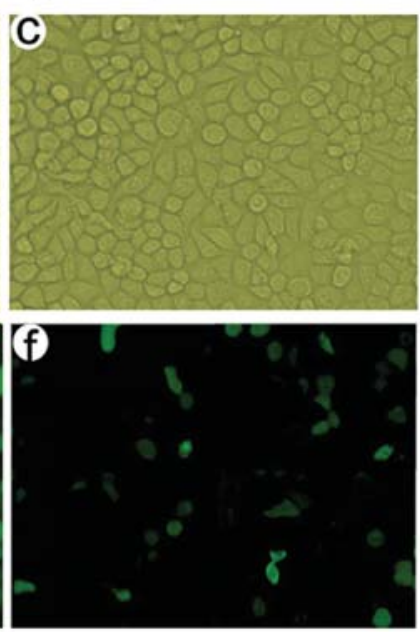

GFP

Phase

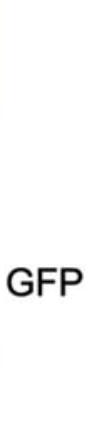

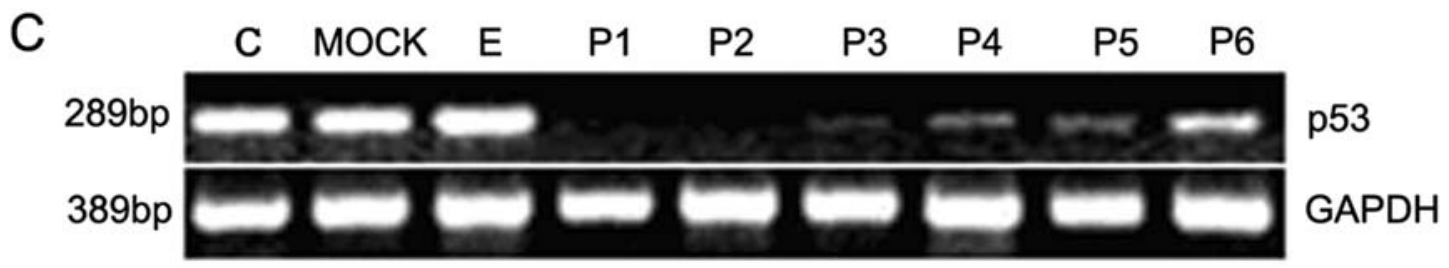

D
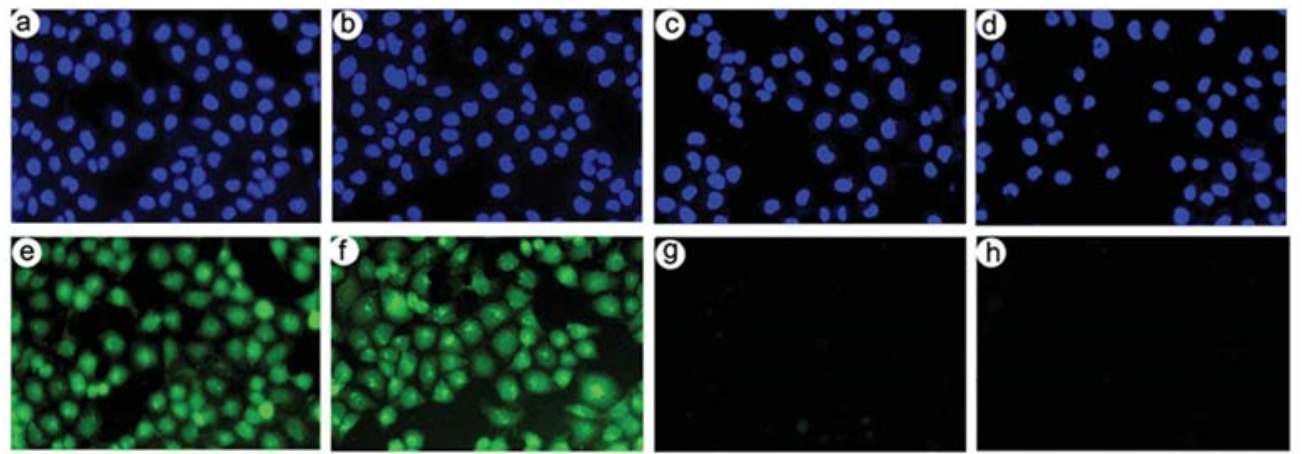

Figure 1. Selective suppression of shRNA on gene expression. (A) Schematic diagram of shRNA expressing system: sequence of the chemically synthesized shRNA encoding DNA oligonucleotides. (B) Fluorescence microscopic observation of CNE2 cells transiently co-transfected with shRNA-expressing plasmids and an eGFP plasmid. a and d, CNE2 cells were transfected with peGFP plasmid (800 ng). b and e, CNE2 cells were co-transfected with 800 ng of peGFP plasmid and $4 \mu \mathrm{g}$ of pSUPER/sip53 plasmid. c and f, $800 \mathrm{ng}$ of peGFP plasmid was cotransfected with $4 \mu \mathrm{g}$ of pSUPER/sieGFP plasmid into CNE2 cells, and eGFP fluorescence was effectively reduced. All images were taken at the same exposure (magnification x40). (C) RT-PCR for detecting the expression level of p53. The positive clones resisted to puromycin were expanded to establish cell lines and analyzed for p53 mRNA levels. C represents CNE2 cell line. Mock represents the cell line transfected with empty vector. E represents the cell line transfected with pSUPER/sieGFP. P represents the cell lines transfected with pSUPER/sip53. GAPDH expression was analyzed as a loading control. (D) Immunofluorescent detection of p53 expression using antibodies against p53 (green) and using DAPI staining nucleus as a corresponding control (blue). The expression of p53 was complete extinct in CNE2sip53-1 (c and g) and CNE2sip53-2 ( $\mathrm{d}$ and $\mathrm{h}$ ) cell lines (p1 and p2 cell lines shown in C), whereas had no significant change in CNE2 (a and e) and CNE2/pSUPER (b and f) which showed obvious nuclear and endochylema accumulation of p53. (Magnification $\mathrm{x} 40$ ).

antibodies (Fig. 2B, lanes 5-12). p53 protein levels were readily induced by IR, followed by the induction of $\mathrm{p} 21$ and HDM2 in CNE2 and CNE2/pSUPER cells. In sharp contrast to the p53 induction in CNE2 and CNE2/pSUPER cells,
Western blot analysis demonstrated that p53 activation in response to IR was severely compromised in CNE2sip53 cells, as evidenced by the significantly diminished induction of p53 target gene products p21 and HDM2. Taken together, 
A

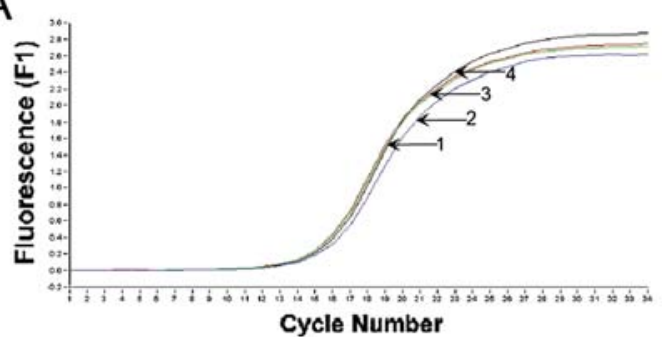

a

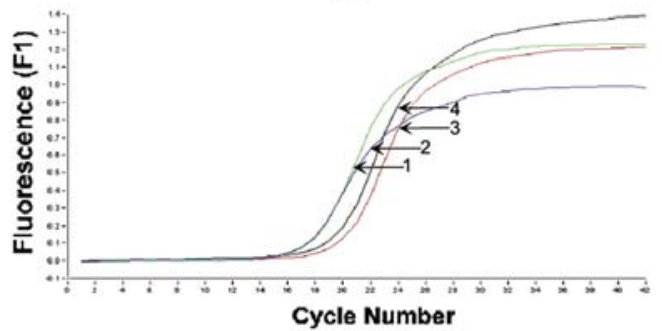

C

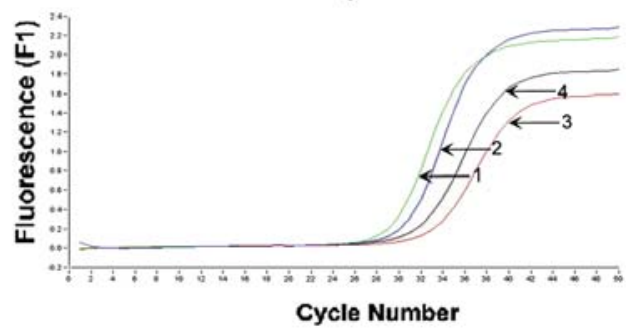

e

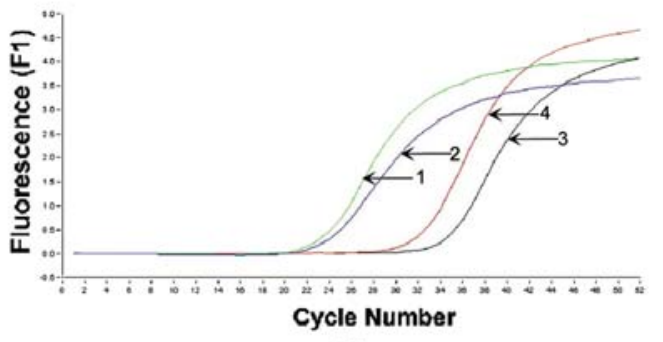

$\mathrm{g}$

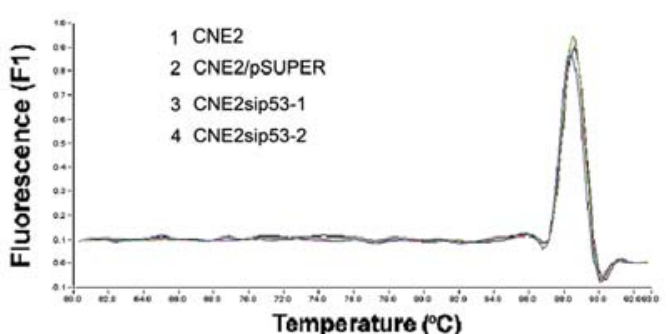

b

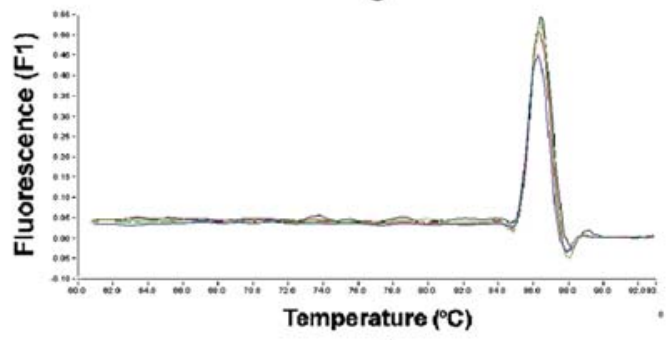

d

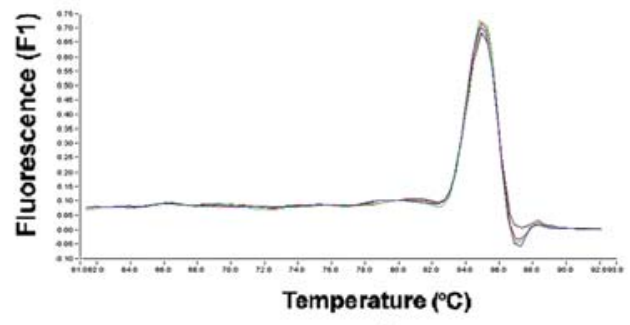

$\mathrm{f}$

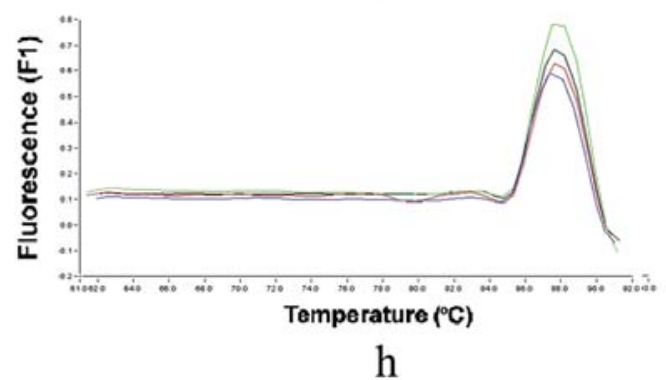

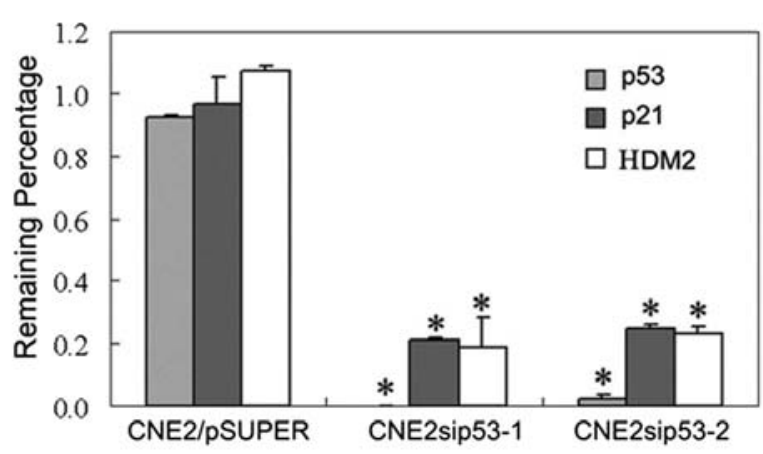

$B_{\text {IR(-) }}$

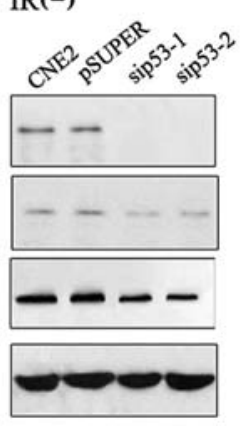

$\operatorname{IR}(+): 3 \mathrm{~h}$

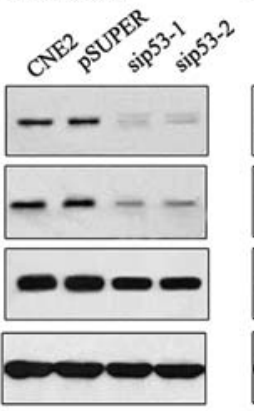

$\operatorname{IR}(+): 6 \mathrm{~h}$

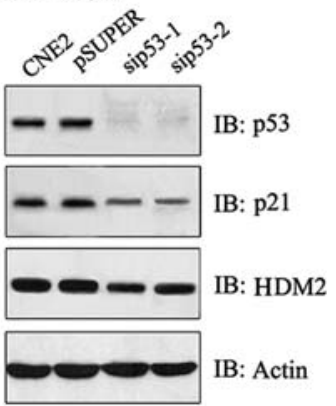

Figure 2. Stable suppression of p53 expression in CNE2 cells and the effects of specific p53 gene inhibition on the expression of p21 and MDM. (A) Representative real-time quantitative RT-PCR analysis for the mRNA level. Graph a shows that mRNA level of GADPH among CNE2, CNE2/pSUPER, CNE2sip53-1 and CNE2sip53-2 had very little difference. Graph c and e show that mRNA levels of p21 and HDM2 decreased in the CNE2sip53-1 and CNE2sip53-2 cell lines representatively. Graph g shows the expression of p53 decreased significantly in CNE2sip53-1 and CNE2sip53-2 cell lines. Graphs b, $\mathrm{d}, \mathrm{f}$ and $\mathrm{h}$, show the melting curve of representative PCR products of GAPDH, p21, HDM2 and p53, respectively. The mRNA expression levels of p53, p21 and HDM2 genes were examined and were normalized to that of GAPDH. Values shown in histogram were remaining percentage in respective mRNA levels relative to GAPDH. "p<0.05 vs. CNE2/pSUPER cell line. (B) Down-regulation of p21 and HDM2 proteins by stable suppression of p53 expression in CNE2 cells. Western blot analysis shows decrease of the level of p21 and HDM2 protein in CNE2sip53 cells in steady state (lanes 1-4). Cells were treated with IR (5 $\mathrm{Gy}$ ) at room temperature and harvested for Western blot analysis at 3 or $6 \mathrm{~h}$ after treatment. Cell lysates were probed using the indicated antibodies. Stable expression of p53 shRNA in CNE2sip53-1 (lanes 7 and 11) and CNE2sip53-2 (lanes 8 and 12) induced a marked reduction in p53 synthesis (first panel) resulting in down-regulation of p21 (second panel) and HDM2 (third panel) compared with CNE2 (lanes 5 and 9) and CNE2/pSUPER (lanes 6 and 10). The fourth blot was probed with anti-ß-actin antibody to control for protein loading (fourth panel). 

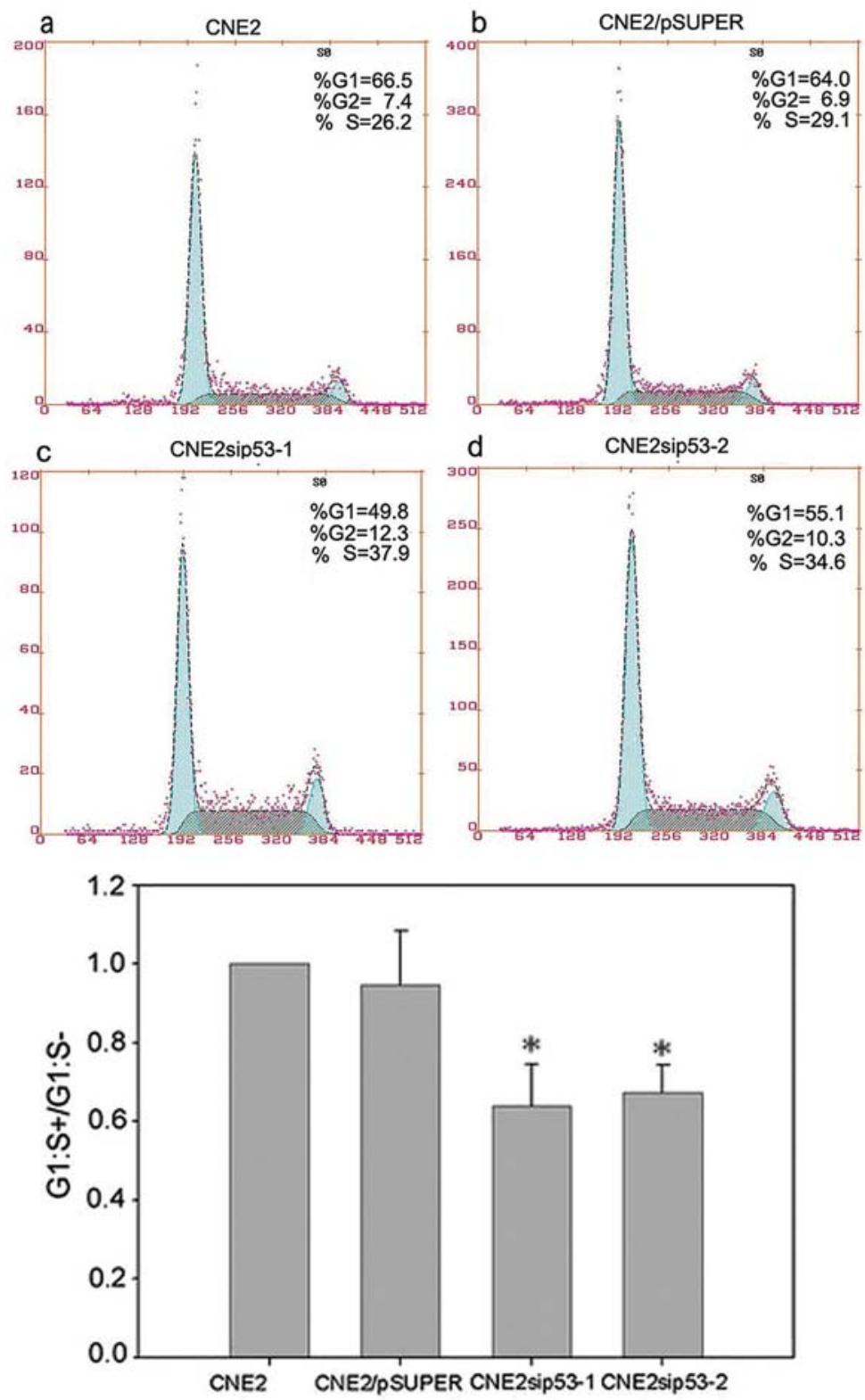

Figure 3. Effects of specific p53 gene inhibition on cell cycle distribution of CNE2 cells. Cell cycle analysis by FACS showed decreases of G1 phase and increases of S phase in CNE2sip53 cell lines ( $c$ and d). The CNE2/pSUPER cell line was hardly changed in G1 phase and S phase compared to the CNE2 cell line (a and b). G1:S+/G1:S- of histogram refers to the decrease in the G1:S ratio observed. Data represent the averages of three experiments. Error bars reflect the SD from the average. Statistical analysis was performed by Student's t-test. "p $<0.05$ vs. cells transfected with vector.

our data indicate that knockdown of overexpressed p53 in the CNE lines in both steady state and genotoxic stress induced by IR resulted in down-regulation of p21 and HDM2, two transcriptional target genes of p53.

We next asked whether the biochemical changes caused by 533 knockdown could be reflected at the level of cell biology. For this, we evaluated the impact of p53 knockdown on cell cycle progression. FACS analysis of CNE2sip53-1 and CNE2sip53-2 cell lines revealed a significant decrease of G1 phase with a corresponding increase of $S$ phase populations when compared with the pSUPER vector expressing lines $(\mathrm{p}<0.05$, Fig. 3), consistent with the down-regulation of p21. Together, our data suggest that overexpressed p53 exerts a negative regulation on cell cycle progression in NPC cells.
Effects of stable inhibition of overexpressed p53 in CNE2 on cell growth and tumorigenesis. To investigate the effects of overexpressed p53 down-regulation on the growth property of CNE2 cells, a number of assays including MTT, monolayer growth experiment and soft agar growth experiment were performed. The MTT assay showed that knockdown of p53 expression in CNE2 cells was associated with a marked increase of cell proliferation (Fig. 4A), suggesting a growth inhibitory activity of p53. This effect of p53 on cell growth was further supported by the results of monolayer and soft agar growth experiments that down-regulation of p53 expression in CNE2 cells resulted in a significant growth enhancement under each condition tested (Fig. 4B and C).

To substantiate the results obtained from in vitro assays for the in vivo relevance, we carried out nude mice tumor 
A

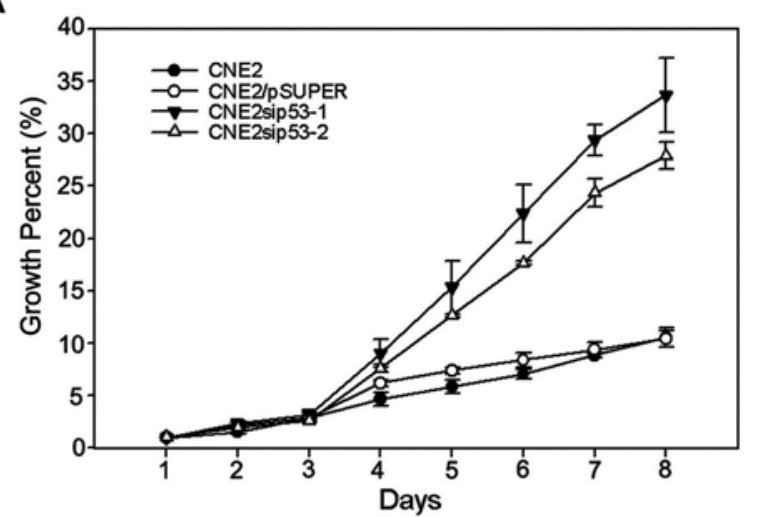

B

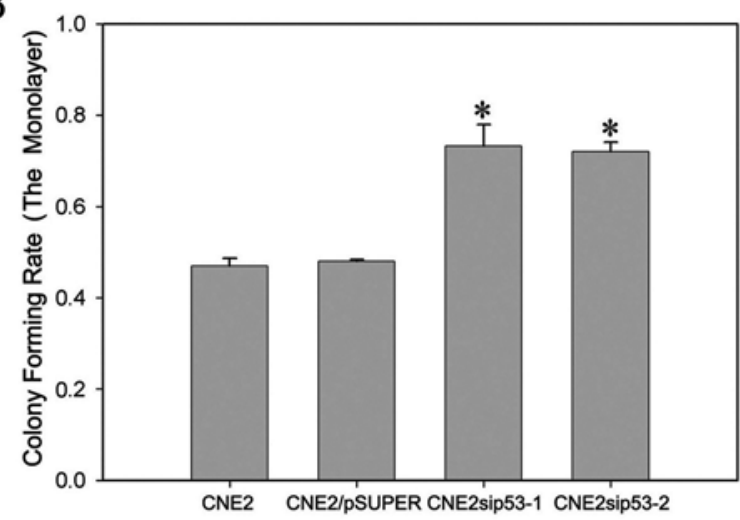

C

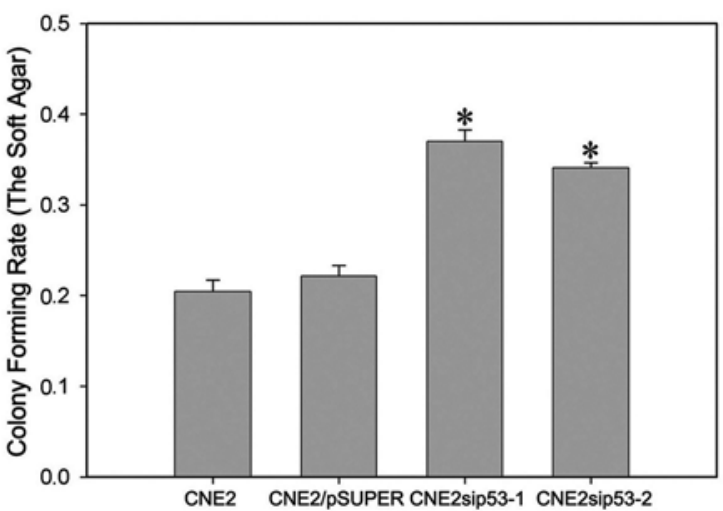

Figure 4. Effects of specific p53 gene inhibition on acceleration of in vitro growth of CNE2 cells. (A) Cells were trypsinized, dispensed into a 96-well plate at 500 cells per well and were grown for 7 days. Every 24 h, the percentage of cell growth was calculated by comparison of the A490 readings versus the first day. (B) The histogram showed the effect of inhibition of p53 expression on the monolayer colony formation of CNE2 cells. 500 cells were plated per well in 6-well plates, and after 7 days colonies of $>50$ cells stained with crystal violet. The monolayer growth of CNE2sip53 cells was detected. Data represent the averages of three experiments. Error bars reflect the SD from the average. ${ }^{*} \mathrm{p}<0.05$ vs. CNE2/pSUPER cells. (C) The histogram showed the effect of inhibition of p53 expression on the soft agar growth of CNE2 cells. For the soft agar growth experiment, cells were trypsinized and resuspended in complete medium containing $0.3 \%$ agar. Cells $\left(1 \times 10^{4}\right)$ were overlaid on medium containing $0.5 \%$ agar in a 6 -well plate. The number of colonies consisting of $>50$ cells was determined 10 days after plating. Data represent the averages of three experiments. Error bars reflect the SD from the average. ${ }^{*} \mathrm{p}<0.05$ vs. CNE2/pSUPER cells.

formation assay. Tumor development was monitored after inoculating $1 \times 10^{7}$ of each cell type subcutaneously into nude mice. As shown in Fig. 5, tumor formation and growth of CNE2sip53 cells was faster than that of CNE2 and CNE2/
pSUPER cells. As early as at day 4 after inoculation, tumors were palpable in all mice $(6 / 6 ; 100 \%$ of animals) inoculated with CNE2sip53 cells, whereas, the six mice received with CNE2 or CNE2/pSUPER cells formed tumor by day 7 following inoculation. Furthermore, tumor growth in mice inoculated with CNE2sip53 cells were significantly more rapid than those inoculated with CNE2 or CNE2/pSUPER cells $\left(\mathrm{p}<0.01\right.$, mean size $1.22 \pm 0.25 \mathrm{~mm}^{3}$ in the CNE2 group, $\mathrm{n}=6$, and $1.09 \pm 0.29 \mathrm{~mm}^{3}$ in the CNE2/pSUPER group, $\mathrm{n}=6$ vs $2.55 \pm 0.71 \mathrm{~mm}^{3}$ in the CNE2sip53 group, $\mathrm{n}=6$ ). Histopathological analysis of the nude mice tumors showed that all were undifferentiated malignancies (data not shown). Together, results from both in vitro and in vivo experiments demonstrate that knockdown of the expression of overexpressed p53 enhanced the ability of CNE2 cells to proliferate and to form tumors.

Effects of overexpressed p53 knockdown on cellular radiosensitivity. As the p53 protein plays an important role in regulation of cellular response to IR, we examined the effect of p53 knockdown in CNE2 cells on radiation sensitivity by performing a clonogenic survival assay. We determined Do values (dose of radiation producing a 37\% survival rate) and $\mathrm{N}$ (extrapolation number) values from the survival curves constructed according to the single-hit multitarget model of cell survival. As shown in dose-effect curves for the loss of colony-forming ability (Fig. 6A), the CNE2 and CNE2/pSUPER cells exhibited a similar radiation sensitivity in the dose range from 1 to $8 \mathrm{~Gy}$, however, the sensitivity of CNE2sip53 cell lines was decreased. The survival fraction at 2 Gy was $0.41 \pm 0.02$ for CNE2 cell line, and $0.40 \pm 0.01$ for CNE2/pSUPER cell line whereas the survival fractions at 2 Gy were $0.65 \pm 0.01$ and $0.66 \pm 0.01$, respectively for the two CNE2sip53 cell lines. The radiosensitivity Do value defined as the reciprocal of the terminal slope of the survival curves was $1.04 \mathrm{~Gy}$ for CNE2 cell line and 1.03 Gy for CNE2/ pSUPER cell line when irradiation was used alone. $\mathrm{N}$ value was 3.38 \pm 0.45 for CNE2 cell line, and 3.26 \pm 0.34 for CNE2/ pSUPER cell line. But in CNE2sip53 cell lines, Do values were 1.30 and 1.31 , and $N$ values were $4.27 \pm 0.39$ and $4.33 \pm 0.57$. The results showed that the radiosensitivity of CNE2sip53 cells were lower than that of CNE2 or CNE2/ pSUPER cells $(\mathrm{p}<0.01)$. Furthermore, radiation-induced apoptosis was also determined at $24 \mathrm{~h}$ following irradiation by Hoechst 33258 staining. After exposure to 6-Gy irradiation, more apoptotic cells were detected in CNE2 and CNE2/ pSUPER cells than in CNE2sip53 cells (Fig. 6B). Quantitative analysis showed up to $22 \%$ decrease of apoptotic population in CNE2sip53 cells when compared with CNE2/pSUPER cells $(\mathrm{p}<0.01$, Fig. 6B), consistent with the data obtained from clonogenic assay that down-regulation of p53 in CNE2 cells resulted in increased radioresistance.

\section{Discussion}

RNAi, which is homologous to the gene being suppressed, is the sequence-specific, post-transcriptional gene silencing method caused by small interfering RNA duplexes (siRNAs) and is rapidly being established and holds promise to specifically inhibit gene expression in mammals (20). Based 

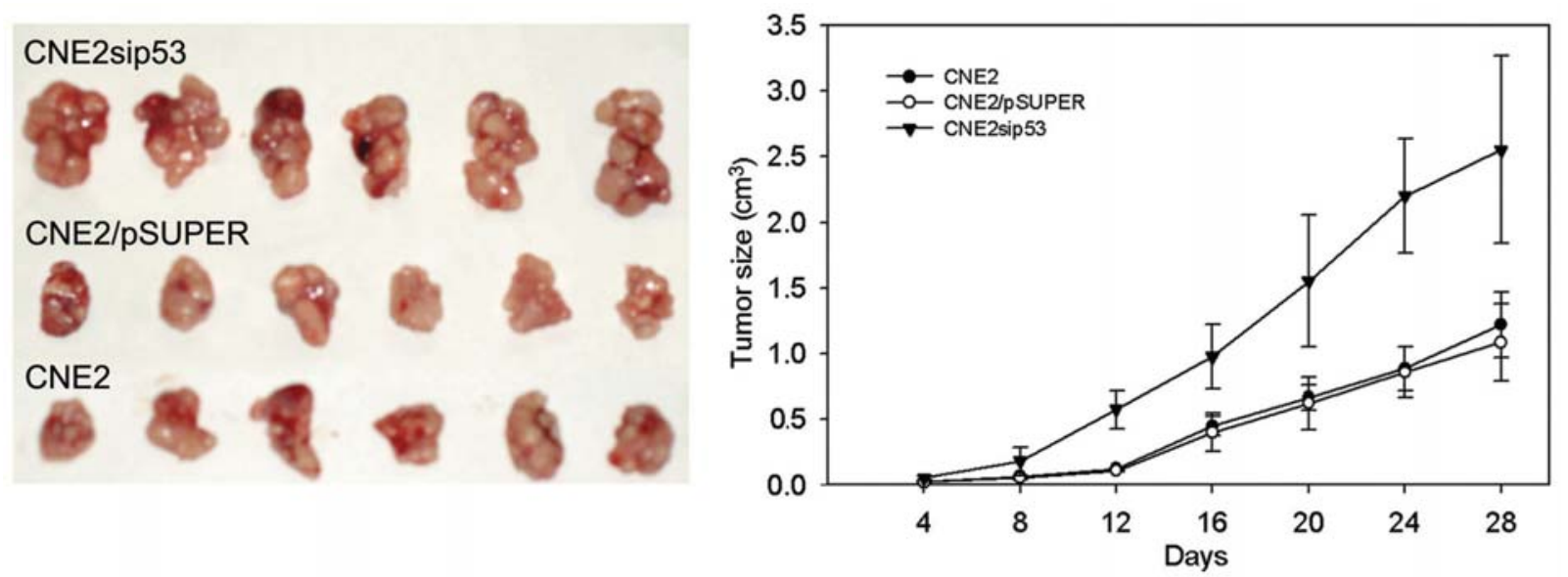

Figure 5. Acceleration of in vivo growth of CNE2 cells in nude mice by stable expression of p53 shRNAs. The graph shows the in vivo tumor growth curves of CNE2, CNE2/pSUPER and CNE2sip53 cells. The tumor volumes were measured every 3 days with calipers. The mean tumor volumes \pm SD (bars) are shown at the times that tumor measurements were made $(\mathrm{n}=6)$. Twenty-eight days later after inoculation, tumors from mice inoculated with CNE2 cells were 2.09-fold smaller than those from mice inoculated with CNE2sip53 cells. The size of tumors from mice inoculated with CNE2/pSUPER cells was not significantly different from those of the group inoculated with CNE2 cells.

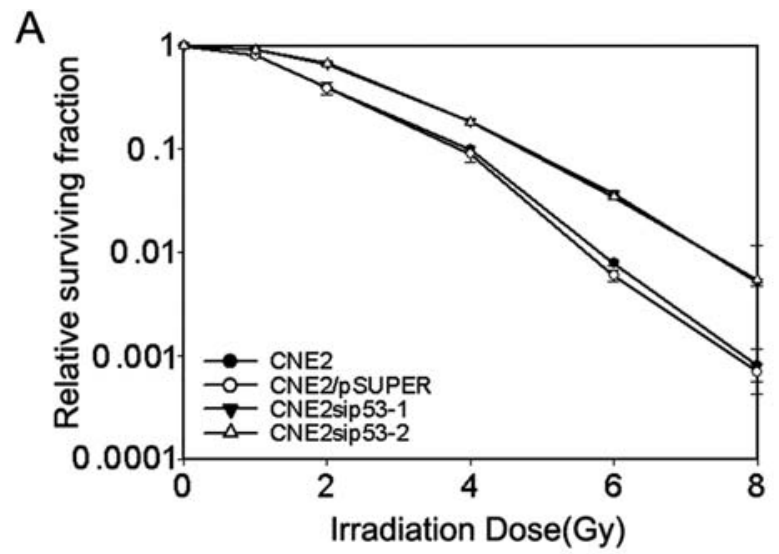

B
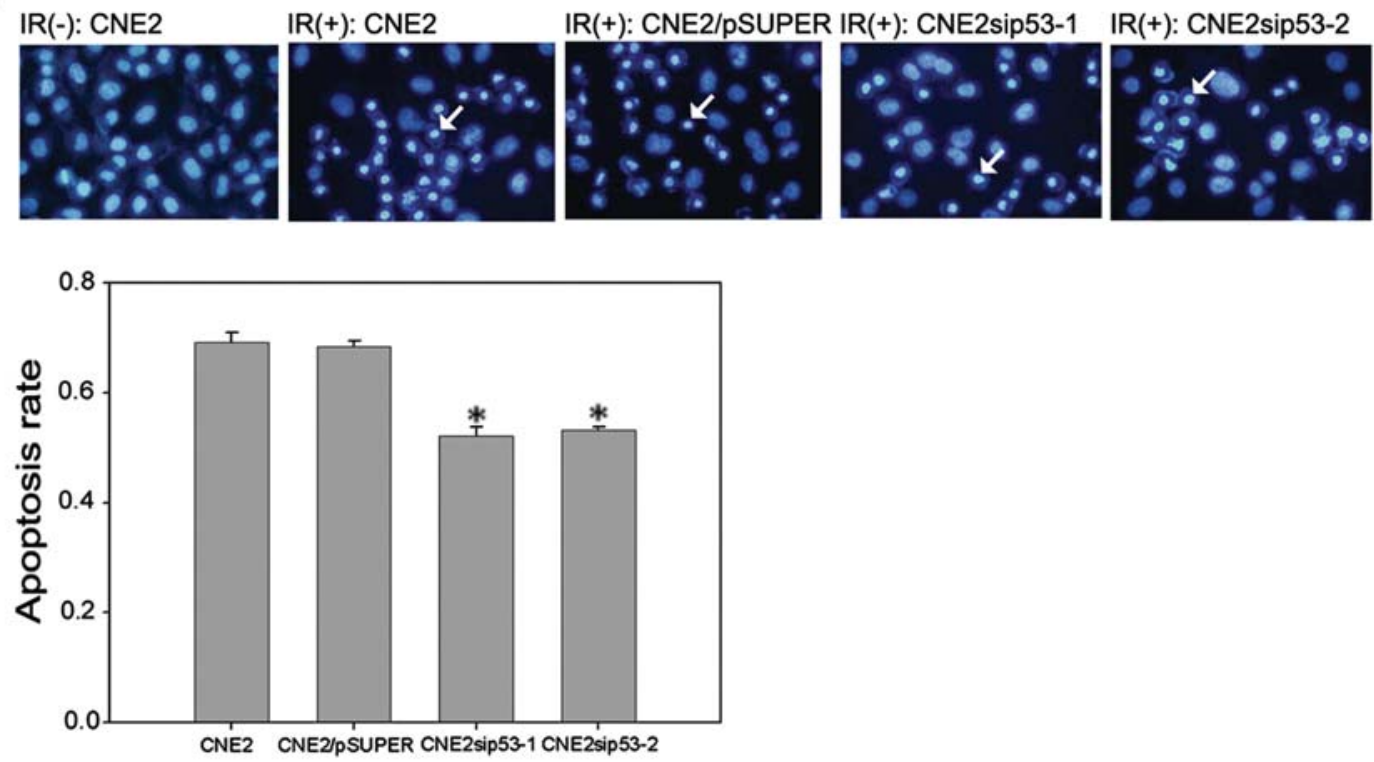

Figure 6. Effect of the specific p53 gene silencing on radiation sensitivity of CNE-2 cells. (A) Effect of p53 knockdown on radiation sensitivity of CNE-2 cells as determined by clonogenic assay. Cells were irradiated with single exposures of $0,1,2,4,6$, or 8 Gy. Fixation and staining of colonies were carried out 10 days later. Then dose-effect curves for the loss of colony-forming ability were established. Data represent the averages of three experiments. Error bars reflect the SD from the average. (B) Stable inhibition of p53 expression increased resistance to cell killing by irradiation. After exposure to 6-Gy irradiation, cells were incubated for $24 \mathrm{~h}$ and then assessed for apoptosis. The nuclear morphology of cells after irradiation or left untreated was studied by using the cellpermeable DNA dye Hoechst 33258. A histogram showed the effect of stable silence of p53 expression on the apoptosis rate of CNE2 cells. The experiment was repeated in triplicate. "p $<0.05$ vs. cells transfected with vector. Representative data from a single experiment are shown. Apoptotic nuclei showing intense fluorescence corresponding to chromatin condensation (arrow) are indicated. (Magnification $\mathrm{x} 40$ ). 
on establishing the CNE2sip53 cell line, which had stable expression of p53 shRNA in CNE2 cell line and satisfactory inhibition of the target $\mathrm{p} 53$ protein expression, the effects of persistent down-regulation of p53 gene expression on the transcriptional inactivation of the p53-responsive genes, and on cell proliferation, cell cycle, and the radiation sensitivity and apoptosis after ionizing radiation were demonstrated.

p53 is primarily a sequence-specific transcriptional activator, which binds to cognate p53 responsive elements within the genome and activates the transcription of genes residing in the vicinity of these binding sites. It is known that p53 tumor suppressor becomes stabilized and activated in response to diverse cellular stresses, such as DNA damage, hypoxia, and oncogene activation. Activation of p53 can cause cell cycle arrest, senescence, differentiation, DNA repair to conserve the genome and apoptosis, which are largely mediated by activation of p53-responsive target genes such as HDM2, p21 (8-10). The inactivation or loss of p53 in a majority of human tumors is a very important molecular alteration in the development of the majority of human cancers $(8,29)$. Attributable largely to its central role in tumorigenesis, alteration of the p53 gene has held the most promise as a molecular prognostic and predictive factor with potential clinical utility (29). p53 overexpression has been identified as having predictive value in survival for several other human malignancies, such as breast, lung and head and neck carcinomas (30-34). Overexpression of $\mathrm{p} 53$ protein has been found in NPC, but its prognostic significance is controversial. Theoretically, overexpression of p53 protein might increase radioresistance; however, its implication on patients with NPC may change from one to another (16,35-38). The reason may be related to the population involved and the defined criteria of p53 overexpression. But lots of previous studies have shown that p53 overexpression in NPC is also associated with the proliferation, micro-vessel density, craniosacral invasion and neck lymph node metastasis of NPC as well as the NPC patients' prognosis, which suggest that overexpressed p53 protein in NPC might be dysfunction or inactivation $(17,19,20)$. Such data would predict a compromised tumor suppressor function of overexpressed p53 in the NPC cell line. Results obtained from the present study, however, indicated otherwise. We employed the RNAi approach to knock down the expression of p53 in CNE2 cells for assessing its biochemical and biological consequences. We obtained compelling evidence indicating that overexpressed p53 in this NPC cell line retained most, if not all, of tumor suppressor activities of p53. We demonstrated that down-regulation of p53 in CNE2 cells was associated with significantly diminished expression of p21 and HDM2, two prototype target genes of p53 (Fig. 2), accelerated cell cycle progression (Fig. 3), elevated proliferation rate and enhanced ability of monolayer growth and anchorage-independent soft agar growth (Fig. 4), increased rate of tumor formation in nude mice (Fig. 5) and increased radioresistance (Fig. 6).

While our data indicate that the endogenous p53 in CNE2 cells remains functionally proficient, the NPC phenotype would implicate some other defects in the p53 pathway. Our previous study showed that twenty-two differentially expressed proteins between the two cell lines such as HSP27, HSP70, hnRNP K, 14-3-3r, and so on had been identified by both MALDI-TOF-MS and ESI-Q-TOF-MS after comparison of the proteomic changes between CNE2sip53 and control cell line CNE2/pSUPER using two-dimensional gel electrophoresis (2-DE), which may be associated with the function of p53 in NPC and might reveal novel p53 signal pathway. These findings provide new clues to elucidate the mechanisms of overexpression and stabilization of p53 in NPC (22). Further studies will be necessary to characterize the upstream and downstream effectors of the p53 pathway in CNE2 cells. On the other hand, p53 overexpression and stabilization in NPC may be via interactions with cellular or viral proteins, especially in the presence of EBV viral proteins that interfere with p53 function (39-43). Analysis of the expression of the $\mathrm{p} 53$ protein by immunohistochemistry on NPC biopsies indicates that p53 accumulation is significantly correlated to the EBV-encoded latent membrane protein 1 (LMP1), which is an oncogenic protein and plays an important role in the carcinogenesis of NPC $(44,45)$. Some reports indicated that LMP1 may block p53-mediated apoptosis by induction of the A20 gene and may be one of the major candidates that could bypass p53 function, but it also disrupts DNA repair $(46,47)$. Modification of the p53 phosphorylation has been proposed to play a critical role in the stabilization and activation of p53. Li et al reported that p53 could be activated and phosphorylated clearly at Ser15, Ser20, Ser392, and Thr81 modulated by LMP1 (48). Further experiments are needed to elucidate the exact role of these proteins in possible p53 overexpression and stabilization. Nonetheless, the functional p53 and its associated radiosensivity, as shown in our study, would have important therapeutical implications.

\section{Acknowledgments}

This work was supported by grants from the National Key Basic Research Program (2002CB513100, 2001CB510207), Ministry of Education of China for Outstanding Scholars of New Era (2002-48), National Natural Science Foundation of China (30000028, 30240056, and 30370642).

\section{References}

1. Licitra L, Bernier J, Cvitkovic E, Grandi C, Spinazze S, Bruzzi P, Gatta $\mathrm{G}$ and Molinari R: Cancer of the nasopharynx. Crit Rev Oncol Hematol 45: 199-214, 2003.

2. Wei WI and Sham JS: Nasopharyngeal carcinoma. Lancet 365: 2041-2054, 2005

3. Jeyakumar A, Brickman TM, Jeyakumar A and Doerr T: Review of nasopharyngeal carcinoma. Ear Nose Throat J 85: 168-184, 2006.

4. Ferlay J, Bray F, Pisani P and Parkin DM: GLOBOCAN 2000: cancer incidence, mortality and prevalence worldwide. Version 1.0. IARC Cancer Base No. 5. IARC Press, Lyon, 2001.

5. Raab-Traub N: Epstein-Barr virus in the pathogenesis of NPC. Cancer Biol 12: 431-441, 2002.

6. Chang ET and Adami HO: The enigmatic epidemiology of nasopharyngeal carcinoma. Cancer Epidemiol Biomarkers Prev 15: 1765-1777, 2006.

7. Jalbout M, Bel Hadj Jrad B, Bouaouina N, Gargouri J, Yacoub S, Zakhama A, Khlifa R and Chouchane L: Autoantibodies to tubulin are specifically associated with the young age onset of the nasopharyngeal carcinoma. Int J Cancer 101: 146-150, 2002.

8. Oren M: Decision making by p53: life, death and cancer. Cell Death Differ 10: 431-442, 2003.

9. Prives C and Hall PA: The p53 pathway. J Pathol 187: 112-126, 1999. 
10. Vogelstein B, Lane D and Levine AJ: Surfing the p53 network. Nature 408: 307-310, 2000.

11. Spruck CH III, Tsai YC, Huang DP, Yang AS, Rideout WM III Gonzalez-Zulueta M, Choi P, Lo KW, Yu MC and Jones PA: Absence of p53 gene mutations in primary nasopharyngeal carcinomas. Cancer Res 52: 4787-4790, 1992.

12. Effert P, McCoy R, Abdel-Hamid M, Flynn K, Zhang Q, Busson P, Tursz T, Liu E and Raab-Traub N: Alterations of the p53 gene in nasopharyngeal carcinoma. J Virol 66: 3768-3775, 1992 .

13. Bachouchi M, Cvitkovic E, Azli N, Gasmi J, Cortes-Funes H, Boussen H, Rahal M, Kalifa C, Schwaab G, Eschwege F, Wibault P and Armand JP: High complete response in advanced nasopharyngeal carcinoma with bleomycin, epirubicin, and cisplatin before radiotherapy. J Natl Cancer Inst 82: 616-620, 1990

14. Ganly I, Soutar DS, Brown R and Kaye SB: p53 alterations in recurrent squamous cell cancer of the head and neck refractory to radiotherapy. Br J Cancer 82: 392-398, 2000.

15. Niedobitek G, Agathanggelou A, Barber P, Smallman LA, Jones EL and Young LS: p53 overexpression and Epstein-Barr virus infection in undifferentiated and squamous cell nasopharyngeal carcinomas. J Pathol 170: 457-461, 1993.

16. Sheu LF, Chen A, Tseng HH, Leu FJ, Lin JK, Ho KC and Meng CL: Assessment of p53 expression in nasopharyngeal carcinoma. Hum Pathol 26: 380-386, 1995.

17. Chow LW, Khoo US, Yuen APW and Wei WI: Expression of p53 in recurrent nodal metastasis from nasopharyngeal carcinoma (NPC). Eur J Surg Oncol 23: 415-418, 1997

18. Roychowdhury DF, Tseng A Jr, Fu KK, Weinberg V and Weidner N: New prognostic factors in nasopharyngeal carcinoma. Tumor angiogenesis and c-erbB2 expression. Cancer 77: 1419-1426, 1996.

19. Shao JY, Ernberg I, Biberfeld P, Heiden T, Zeng YX and Hu LF: Epstein-Barr virus LMP1 status in relation to apoptosis, p53 expression and leucocyte infiltration in nasopharyngeal carcinoma. Anticancer Res 24: 2309-2318, 2004

20. Wang LF, Chai CY and Kuo WR: The prognostic value of proliferating cell nuclear antigen (PCNA) and p53 protein expression in patients with advanced nasopharyngeal carcinoma. Acta Otolaryngol 126: 769-774, 2006.

21. Elbashir SM, Harborth J, Lendeckel W, Yalcin A, Weber K and Tuschl T: Duplexes of 21-nucleotide RNAs mediate interference in cultured mammalian cells. Nature 411: 494-498, 2001.

22. Sun Y, Yi H, Zhang PF, Li MY, Li C, Li F, Peng F, Feng XP, Yang YX, Yang F, Xiao ZQ and Chen ZC: Identification of differential proteins in nasopharyngeal carcinoma cells with p53 silence by proteome analysis. FEBS Lett 581: 131-139, 2007.

23. Livak KJ and Schmittgen TD: Analysis of relative gene expression data using real-time quantitative PCR and the 2(-Delta Delta C (T)). Methods 25: 402-408, 2001

24. Tamura K, Southwick EC, Kerns J, Rosi K, Carr BI, Wilcox C and Lazo JS: Cdc25 inhibition and cell cycle arrest by a synthetic thioalkyl vitamin K analogue. Cancer Res 60: 1317-1325, 2000.

25. Mosmann T: Rapid colorimetric assay for cellular growth and survival: application to proliferation and cytotoxicity assays. J Immunol Methods 65: 55-63, 1983 .

26. Colombel M, Filleur S, Fournier P, Merle C, Guglielmi J, Courtin A, Degeorges A, Serre CM, Bouvier R, Clezardin P and Cabon F: Androgens repress the expression of the angiogenesis inhibitor thrombospondin-1 in normal and neoplastic prostate. Cancer Res 65: 300-308, 2005

27. Hallahan DE, Spriggs DR, Beckett MA, Kufe DW and Weichselbaum RR: Increased tumor necrosis factor alpha mRNA after cellular exposure to ionizing radiation. Proc Natl Acad Sci USA 86: 10104-10107, 1989

28. Perez-Ortiz JM, Tranque P, Vaquero CF, Domingo B, Molina F, Calvo S, Jordan J, Cena V and Llopis J: Glitazones differentially regulate primary astrocyte and glioma cell survival. Involvement of reactive oxygen species and peroxisome proliferatoractivated receptor-gamma. J Biol Chem 279: 8976-8985, 2004

29. Bosari S and Viale G: The clinical significance of $\mathrm{p} 53$ aberrations in human tumors. Virchows Arch 427: 229-241, 1995.

30. Caffo O, Doglioni C, Veronese S, Bonzanini M, Marchetti A, Buttitta F, Fina P, Leek R, Morelli L, Palma PD, Harris AL and Barbareschi M: Prognostic value of p21(WAF1) and p53 expression in breast carcinoma: an immunohistochemical study in 261 patients with long-term follow-up. Clin Cancer Res 9: 1591-1599, 1996.
31. Berns EM, Foekens JA, Vossen R, Look MP, Devilee P, Henzen-Logmans SC, van Staveren IL, van Putten WL, Inganas M, Meijer-van Gelder ME, Cornelisse C, Claassen CJ, Portengen $\mathrm{H}$, Bakker B and Klijn JG: Complete sequencing of TP53 predicts poor response to systemic therapy of advanced breast cancer. Cancer Res 60: 2155-2162, 2000.

32. Kawasaki M, Nakanishi Y, Kuwano K, Yatsunami J, Takayama K and Hara N: The utility of p53 immunostaining of transbronchial biopsy specimens of lung cancer: p53 overexpression predicts poor prognosis and chemoresistance in advanced nonsmall cell lung cancer. Clin Cancer Res 3: 1195-1200, 1997.

33. Quon H, Liu FF and Cummings BJ: Potential molecular prognostic markers in head and neck squamous cell carcinomas. Head Neck 23: 147-159, 2001

34. Temam S, Flahault A, Perie S, Monceaux G, Coulet F, Callard P, Bernaudin JF, St Guily JL and Fouret P: $p 53$ gene status as a predictor of tumor response to induction chemotherapy of patients with locoregionally advanced squamous cell carcinomas of the head and neck. J Clin Oncol 18: 385-394, 2000.

35. Genc E, Hosal AS, Gedikoglu G, Ozyar E and Sozeri B: Prognostic value of $\mathrm{p53}$, proliferating cell nuclear antigen, and $\mathrm{Ki}-67$ expression in undifferentiated nasopharyngeal carcinomas. Otolaryngol Head Neck Surg 122: 868- 873, 2000.

36. Faccioli S, Cavicchi O, Caliceti U, Rinaldi Ceroni A and Chieco P: Cell proliferation as an independent predictor of survival for patients with advanced nasopharyngeal carcinoma. Mod Pathol 10: 884-894, 1997

37. Shi W, Pataki I, MacMillan C, Pintilie M, Payne D, O'Sullivan B, Cummings BJ, Warde P and Liu F-F: Molecular pathology parameters in human nasopharyngeal carcinoma. Cancer 94: $1997-2006,2002$

38. Ma BB, Poon TC, To KF, Zee B, Mo FK, Chan CM, Ho S, Teo PM, Johnson PJ and Chan AT: Prognostic significance of tumor angiogenesis, Ki-67, p53 oncoprotein, epidermal growth factor receptor and HER2 receptor protein expression in undifferentiated nasopharyngeal carcinoma - a prospective study. Head Neck 25: 864-872, 2003.

39. Scheffner M, Werness BA, Huibregtse JM, Levine A and Howley P: The E6 oncoprotein encoded by human papillomavirus types 16 and 18 promotes the degradation of $\mathrm{p} 53$. Cell 63: 1129-1136, 1990.

40. Lechner M, Mack D, Finicle A, Crook K, Vousden K and Laumins L: Human papillomavirus E6 proteins bind p53 in vivo and abrogate p53-mediated expression of transcription. EMBO J 11: 3045-3052, 1992

41. Yew P and Berk A: Inhibition of p53 transactivation required for transformation by adenovirus early 1B protein. Nature 357 : $82-85,1992$

42. Zhang Q, Cutsch D and Kenny S: Functional and physical interaction between p53 and BZLF1: implications for EpsteinBarr virus latency. Mol Cell Biol 14: 1929-1938, 1994.

43. Momand J, Sambetti GP, Olson DC, George D and Levine AJ: The mdm- 2 oncogene product forms a complex with the p53 protein and inhibits p53 mediated transactivation. Cell 69: $1237-1245,1992$

44. Cheung FM, Pang SW, Yau TK, Chow SK and Lo KW: Nasopharyngeal intraepithelial lesion: Latent Epstein-Barr virus infection with malignant potential. Histopathology 45: 171-179, 2004.

45. Murono S, Yoshizaki T, Park CS and Furukawa M: Association of Epstein-Barr virus infection with p53 protein accumulation but not bcl-2 protein in nasopharyngeal carcinoma. Histopathology 34: 432-438, 1999

46. Fries KL, Miller WE and Raab-Traub N: Epstein-Barr virus latent membrane protein 1 blocks p53-mediated apoptosis through the induction of the A20 gene. J Virol 70: 8653-8659, 1996.

47. Liu MT, Chen YR, Chen SC, Hu CY, Lin CS, Chang YT, Wang WB and Chen JY: Epstein-Barr virus latent membrane protein 1 induces micronucleus formation, represses DNA repair and enhances sensitivity to DNA-damaging agents in human epithelial cells. Oncogene 23: 2531-2539, 2004.

48. Li L, Guo L, Tao Y, Zhou S, Wang Z, Luo W, Hu D, Li Z, Xiao L, Tang M, Yi W, Tsao SW and Cao Y: Latent membrane protein 1 of Epstein-Barr virus regulates p53 phosphorylation through MAP kinases. Cancer Lett 255: 219-231, 2007. 